\title{
An Evolutionary Overview of the Joint Researches on B2B Marketing and COO Effect
}

\author{
Marcus Vinicius Costa de Melo e Silva \\ Science in Business Administration \\ The University of São Paulo (USP)
}

Av. Bandeirantes 3900, Monte Alegre, Ribeirão Preto (SP). Brazil

CEP: 14040-905Ｅ-mail: Marcus.Melo@br.endress.com

Janaina de Moura Engracia Giraldi

Associate Professor at the University of São Paulo (USP)

Av. Bandeirantes 3900, Monte Alegre, Ribeirão Preto (SP). Brazil

CEP: 14040-905. Tel: 55(16) 3315-4970Ｅ-mail: jgiraldi@usp.br

Received: July 24, 2016 Accepted: August 30, $2016 \quad$ Published: October 1, 2016

doi:10.5296/jmr.v8i4.9872 URL: http://dx.doi.org/10.5296/jmr.v8i4.9872

\begin{abstract}
This paper is the result of a literature review on business-to-business marketing, and the country-of-origin effect, presenting an evolutionary overview on these topics throughout four decades. The findings indicate that the1970s served as scenario for the introduction of country-of-origin and B2B marketing altogether. During the 1980s, the topic was scarcely explored, being revisited in the next decade, with the addition of more countries and dimensions to the analysis. In the 1990s, the construct country-of-origin effect was dismembered into three others: country of assembly, design, and manufacturing. Finally, the 2000s served as setting for the most complex research of four decades analyzed. The conclusion of this literature review brings a graphical representation that displays the cited authors and their research, the countries involved in the assessments and, the theoretical gaps for further studies.
\end{abstract}

Keywords: M310 Marketing, M370 Advertising, M160 International Business Administration, L15, Information and Product Quality, Standardization and Compatibility. 


\section{Introduction}

Since the 1970s, publications on the topic Marketing Business to Business (also known as $\mathrm{B} 2 \mathrm{~B}$, industrial or organizational marketing) have significantly increased in quantity. Such increment mainly refers to the emergence of specialized journals in this area, such as pioneering the Industrial Marketing Manager, according to LaPlaca and Katrichis (2009). The first book on this subject was written in 1930 and the first article was published in 1934 respectively by Copeland (1930 apud Reid and Plank, 2000, p. 10) and Frederik (1934 apud Reid and Plank, 2000, p. 10).

The onset of such process begins in the 1970's with the raising of questionings on how professionals in the field of organizational transactions performed their duties, acting as buyers. In this interim, perception is one of the most important psychological processes of individuals that ultimately emerges. As a rule, the stimuli to which organizational buyers shall deal with and hence, their perceptions clearly influence or shape the buying process (White, 1979).

Therefore, organizational buying involves people who need to make decisions. Even before the statement that such decisions are rational, all individuals undergo emotional influences (Quester et al., 2000). Thus, with the aim of understanding the relationship between such perceptions, emotions and purchase behavior, one must consider an important aspect in the psychology of individuals, which are the stereotypes imposed on persons or goods from other countries (White, 1979).

Regarding such stereotypes, almost five decades before, Schooler (1965) had already identified substantial differences in consumers' evaluation on virtually identical goods among themselves, except for the made-in information, which refers to country-of-origin. Such information would impact buyers' attitudes and purchasing behavior and, since then, has received several definitions. In general terms, COO (the Country-of-Origin Effect) can be defined as the impact of the fact "country-of-origin" of a product or brand produces on people's behavior and attitudes (Giraldi et al., 2011). To Laroche et al. (2003), research on the image of countries have grown rapidly, and such issue has become critically important for international marketing and trading, assisting both in theory and practice, companies that market their products globally.

The manufacturing and the purchase process of various products are subject to globalization. In this sense, Urbonavičius and Gineikienè (2009), and Usunier (2006) claim that, despite the apparent decline of practical questions over the $\mathrm{COO}$ effect, there are still strong attitudes of buyers upon the fact that a product is domestic or imported. Therefore, as such attitudes strengthen the importance of the $\mathrm{COO}$ factor, this shall remain as a considerable impact within the context of globalization.

Despite the caveat in a prior publication, Ahmed and d'Austous (1995) concluded that this effect is especially true when the only attribute considered is the country-of-origin (which can be defined as a single cue, having no further information considered). In the same sense, additional extrinsic cues must be followed to prevent the overestimation of COO (Ahmed and 
d'Astous, 1995).

Back to the context of organizational buying, subsequent information about a product may lessen the impact upon the organizational buyer's understanding, which takes the role of risk moderator when buying products or services from another organization (Knight et al., 2007).

According to LaPlaca (2008), between 1971 and 2006, the B2B literature comprised only 478 articles in specific journals on organizational marketing, which were outnumbered by the research on the relationship between firms (498) and sales / management (494). As the country-of-origin belongs to the research concerning consumer behavior (Peterson and Jolibert, 1995), one can infer that the number of publications involving this subject in the B2B environment is extremely low.

LaPlaca and Katrichis (2009) found that $13.65 \%$ of all industrial marketing articles published between 1936 and 2006 analyzed the organizational consumer behavior. It is noteworthy that the publications on the subject B2B marketing always occurred at low frequency in the literature. Reid and Plank (2000) conducted an extensive and rich research on B2B marketing, reviewing 2,194 articles and book chapters books written between 1978 and 1997. Such works addressed planning, organizational buying behavior, marketing research, segmentation and demand forecasting, management products, setting prices, creating channels and promotion. All these data show a low occurrence of B2B topic.

A questioning that may arise consists of what makes the number of publications on B2B so scarce as to compare it to B2C. LaPlaca and Katrichis (2009) claim that many companies hold rich databases, with relevant information that could be used to enrich the research of B2B marketing. However, professionals in this field ought to display more availability when invited to engage in research. Moreover, in order to change the imbalance over the production contrasting the final consumer marketing towards the organizational consumer marketing, it is crucial to accept the challenges upon understanding that both issues have their differences, which is commonly neglected by marketing researchers and marketing practitioners. Further, the bias against $\mathrm{B} 2 \mathrm{C}$ comes from the practical experiences of the researchers themselves: scarce scholars have their onset through discussions over bearings or heavy machinery, but on their buying behavior as consumers (LaPlaca and Katrichis, 2009).

Therefore, in view of the actual relevance of $\mathrm{B} 2 \mathrm{~B}$ and $\mathrm{COO}$, this paper aims to bring to light the work already published in the literature involving the two topics as well as the direction that both have followed together. Likewise, the theoretical importance of this article is given by the consolidation of the body of research on the subject amid a diminutive universe, and indicating the proposals for future research suggested by their authors, so that current researchers are able to identify which gaps are yet to be studied. This study can thus be characterized as an exploratory research, that has employed the literature review in these two topics: business-to-business marketing and the country-of-origin effect

The present research paper begins with a comprehensive delve into articles on B2B Marketing. The moderator of choice within that universe was the topic COO, resulting in a total of only sixteen publications. From this point on, one can observe the trajectory of 
publications devoted to the subject within the B2B marketing literature in the period from the early 1970's to the late 2000's through the work of Reid and Plank (2000) and LaPlaca and Katrichis (2009). In this sense, a timeline shows the evolution of COO on B2B. Subsequently, The analysis held comprehends the period from Nagashima (1970) to Chen and Su (2011). The conclusion of this literature review brings a graphical representation that displays the cited authors and their research, the countries involved in the assessments and, the theoretical gaps for further studies.

\section{Results and Discussion}

The theme COO has become one of the most important in the world of business and international marketing, offering valuable support, both in theory and practice, for companies that market their products worldwide.

Nevertheless, it is possible to observe a modest production of publications on the subject in the context of organizational buying. Initially, an incipient, yet earnestly innovative movement arose in the 1970s (Håkansson and Wootz, 1975; Nagashima, 1970, 1977; White, 1979; White and Cundiff, 1978). Afterwards, there is a publication in the early 80s (Cattin et al., 1982); a hiatus of nearly a decade for a number of publications of Ahmed and d'Austous (1993, 1995, 1996) and one paper by Ghymn et al. (1999). Finally, one can notice a similar contribution in the volume of publications in the 2000s (Ahmed et al., 2005; Chen and Su, 2011; Eggertsson, 2010; La et al., 2005; Quester et al., 2000 and others not mentioned here). The contributions of each period follow below in chronological order.

\subsection{Contributions from the 1970 s}

In the early 1970s, a concern emerged about how the "made-in" label could impact international organizational consumers. Nagashima (1970), the first author to use the term "country image," raised the following research problem: How are the products from a particular country perceived by international organizational consumers? What is the relationship between the image of an alien product and international marketing strategies? Based on such questionings, the author analyzed the impact that the "made in" label caused to the image of a given foreign product as regard to both Japanese and American business executives. Accordingly, the researcher found that Japanese executives associated the 'Made in USA' label with high costs. That was mainly due to the engineering and marketing background available in the United States at that time.

In contrast, Japanese executives associated products from Japan with low prices, ordinary goods of basic needs, and the lack of care and cheap labor. In contrast, the Germans saw Japanese products more positively. Meanwhile, the Germans were perceived by other countries as producers of "heavy" industry. The Japanese respondents believed that English goods were luxurious and expensive, yet reliable, crafted carefully and richly in detail. The British goods appeared as inventive, but not as much as American and German products.

As for the U.S executives, British goods were aesthetically less appealing than the German ones. The Japanese buyers acknowledged French products as unique, handcrafted, and exquisite regardless the industry. All countries surveyed believed that the French products 
were the most expensive and extremely prestigious ones among all investigated countries.

Five years later, Håkansson and Wootz (1975) sought to explain the influence of location and size within the supplier selection criteria of Swedish buyers. The chosen countries were Sweden, England, Germany, France and Italy. The selected trading items were screws (standard and special), paints and industrial tools. The authors concluded that the location of the supplier is a variable considered in purchasing decisions of respondents organizational buyers - even more than the size of the supplier. Buyers are sensitive to location, especially concerning buying decision for more complex products (in this case, special screws and industrial tools). In addition, Swedish suppliers exhibit a greater preference in this choice when compared to the other analyzed countries. The authors proposed research on situations where the level of uncertainty in the purchase may be systematically varied.

Subsequently, Nagashima (1977) published a work that replicated his previous study, but before a new scenario, the global economy affected by a substantial increase in inflation. In addition, there was a potential change of mindset of organizational buyers. The questioning covered how Japanese businessmen perceived the products from the United States, Germany, England and France. The findings show that the status of products manufactured in the United States had fallen, while the status of the German and Japanese products rose. The perceived price of U.S. products remained virtually unchanged. Nevertheless, due to inflation over the world economy, the Japanese and German products increased the overall prices; thus reaching the same level of understanding of respondents on prices of U.S. products. Moreover, the United States was still seen as a country of "advanced technology," "mass production," and "global distribution", yet having lost crucial positions to other countries on all referred items.

Concurrently, perceptions about Japanese products enhanced. Products from Japan ceased to be regarded as inferior and low-cost; becoming as expensive as the U.S. products, and reasonably priced when compared to German products. In the meantime, the latter reached the top position among the countries analyzed, with respect to the inventiveness and technology, as well as careful and meticulous manufacturing. Preliminary perception about English products qualified them as modern, coming from a cutting-edge society. Eventually, this concept fell considerably in the evaluation of the decision makers. Finally, perceptions about French products followed almost unchanged with good indicators; Japanese executives believed that those goods aggregated higher prestige and status.

In the following year, White and Cundiff (1978) investigated the psychological impact of price on product evaluation over organizational buyers, especially regarding the quality of those products. Considering the difficulty in seeking additional attributes to influence B2B buying decisions other than quality, the authors searched for other clues; therein, the information "country-of-origin." In that decade, the studies about COO were latent, which certainly served as motivation for the development of research. West Germany, United States, Japan, and Brazil had their products reviewed. The respondent audience consisted of members of the National Association of Purchasing Management in the United States.

Among the conclusions concerning the $\mathrm{COO}$ effect, the authors found a previously built 
stereotype assigned to the analyzed countries. Either positive or negative, such prior conventions had an impact on the buying behavior of industrial managers for affecting their perception of quality. In the mindset of those buyers, the U.S. and Germany stood at the top of the ranking the authors devised according to the understanding the respondents described. In that ranking, Japan was cited after the two former countries, and Brazil ranked at the last place. Therefore, the decision on country-of-manufacture would demand deep and careful consideration.

Finally, the contribution of White (1979), later often quoted by other authors, also underwent previous directions. Therein, it was sought to determine possible stereotypes that purchasing managers of U.S. companies would have on industrial products manufactured in England, France, Italy and West Germany as well as in the U.S. per se. The focus was drawing a parallel between the $\mathrm{COO}$ effect, and three dimensions: quality, price and 'marketing features' - promotion, for example. White (1979) found that stereotypes about products traded between the nations addressed, in fact, existed. Regarding the dimension of quality, the German products were considered superior to the others. The goods from France, England and the U.S. showed the same level of quality. The English and American products displayed a higher level of quality than the Italians.

The author's third discovery, a substantially important one, was related to the price. Bearing the image of a country that sells expensive products, occasionally associating high prices with quality, could be harmful. That was because organizational buyers discern between quality dimensions and price more rationally. Therefore, the higher the rank of the country in the dimension of price is, the more the country was seen as a seller of expensive products, with low rationality about price creation.

\subsection{Contributions from the $1980 \mathrm{~s}$}

Among all analyzed decades, the 1980s was clearly the most scarce in contributions on B2B and COO combination. Cattin et al. (1982) only replicated the methods of Nagashima (1970, 1977) and White (1979). The authors analyzed products of the same countries that the two former authors had studied, but considering purchasers of companies in the United States and France. Accordingly, respondents preferred products of their countries in the first place, from West Germany secondly, and finally, the products from Japan.

For the Americans, the made in concept was the most favorable for products manufactured in West Germany, in contrast to English and French products. Japanese products have attracted few positive feedbacks from French purchasing managers, unlike the English products, which were considered "creative" and luxurious for the latter managers. For French buyers, German products seemed to be more expensive, heavy industry-oriented, less technically advanced, which was less intense according the American buyers.

Finally, according to French buyers, the Americans were more expensive, with a broad assortment of brands that they did not know. American buyers saw French products as less reliable and easily copiable. At that time, the authors had indicated due care with the use of the made-in label. In this sense, the authors proposed the adoption of positive 
communications for the image of the country-something that, for the most part escapes the purview of companies. Likewise, they suggested associations with local institutions to strengthen the company, with little or no communication about the country-of-origin. As a theoretical gap, the authors left no space to discover which variables explain how to purchase directors create the image on products made in other countries.

From 1982 to 1985 , the priority in the marketing literature was the marketing environment and its constituent elements, such as advertising. The late 1970s brought to light an emphasis on communication with the final consumer. For instance, the businesses gained strength with the advent of a novelty: the television. Thus, the concern about the manner and amount of advertisements to make had gained prominence. Many new studies have emerged to reach an understanding on the end-consumer-market and the communication with such consumer (Wilkie and Moore, 2003). Significantly, from 1986 to 1990 there was no topic seen as a priority. Along the decade and due to limitations on research, further analysis and research methods, the following concerns arose: public policies, marketing ethics, consumer economy, social marketing, international consumer policies, and macromarketing.

\subsection{Contributions from the 1990s}

Throughout the 1990s, Ahmed and d'Astous (1993) started a series of publications on the $\mathrm{COO}$ effect within B2B. The first paper showed that the greater the involvement of consumers with the purchase was, the higher the chances were that they would use the country-of-origin information on product evaluation. Meanwhile, Kraft and Chung (1992) analyzed the reviews of professionals from Korea about American and Japanese exporters, about the products they offered (considering design, quality and price) and their own characteristics (reputation, knowledge of other cultures, trading style and communication).

The authors found that the Japanese had better ratings in practically all dimensions (the Americans were slightly better in the dimension of interpersonal communication And as exporters of finished goods rather than raw materials). In conclusion, factors related to characteristics of exporters would strongly influence the decision of importing U.S. products. Indeed, such features should be considered by Americans when exporting their products to the Korean market.

Subsequently, Ahmed and d'Astous (1993) addressed hybrid products, i.e., manufactured in a particular country but under a brand from another country. They investigated the effects of three countries of origin, three distinctive brands and the levels of perception on prices and services involving hybrid cars through interviews with Belgian and Canadian consumers. However, this analysis contemplated the B2C market. Two years after this work, the same authors carried the concept of hybrid products into the B2B context. The object of study was the judgment of the quality and purchase value of three different product categories, according to 173 purchasing managers (average of 14 years of activity in purchases) and 190 domestic consumers. In the context of hybrid products, the made-in concept focused on products manufactured in Mexico, at that time, a newly industrialized, considering the scarce publications on $\mathrm{COO}$ at that time. The hybrid nature of products can potentially directly affect brand awareness, which is usually associated with the country where the company has 
its headquarters (Ahmed and d'Astous, 1995).

In order not to overestimate the $\mathrm{COO}$ effect, the authors' approach also included brands, warranty and price as extrinsic and additional clues. An important contribution of this study was to compare the behavior of organizational buyers with domestic consumers - something that, according to the authors, had not been done in previous works involving COO. Furthermore, two factors related to country image perception appear: buyer-perceived quality, and the purchase amount. The choice of products also brought to light the lack of studies with different levels of complexity for each product evaluated. The authors included different levels of financial risk acquisition, technological complexity, and purchase challenge.

Ahmed and d'Astous (1995) found that products from developed countries exhibit better evaluation of buyers in comparison to products from newly industrialized countries. Nevertheless, these latter countries are better evaluated as assemblers than designers. Another finding indicates the existence of concrete differences in perceptions toward products from organizational consumers in contrast to the views of household consumers.

Consequently, having "perceived quality" and "purchase price" as dependent variables led to the discovery that the effect caused by the country-of-design (COD) explained a large proportion of the variance for products of high and medium involvement (related to the complexity degree of product). In this sense, organizational buyers gave more value to this construct than household buyers, so as to country of assembly (COA) - on a smaller scale, however. COD earned greater attention than brand and COA before organizational buyers and COO had less distinction than the brand for household consumers. Organizational buyers prefer products designed in developed countries, assembled in newly industrialized countries. In addition, information containing the name of the brand, price and warranty had a superior impact on the perceived quality and purchase value of products for both buyers - particularly household consumers, who cherish brand and product warranty whereas organizational consumers turn to price. Therefore, effects of COD and COA on both organizational and household buyers showed attenuation with the availability of other information; in view of the above, brand, price, and warranty.

In 1998, the authors published another work, but into the B2C context. They conducted interviews with Chinese and Canadian consumers, analyzed six product categories. Such consumer goods (VCRs, T-shirts, cars, shoes, refrigerators, cameras) presented different types of involvement with respect to their processes. Similarly, COD had more influence than the brand itself and, particularly in the Chinese market, consumers strongly associated the price with the quality of those sorts of products.

In 1999, the same authors presented the results of other research; about this about a product with an average level of involvement purchase, and trying to analyze how the COO influences consumers at the time of purchase evaluation. Respondents this time were 277 retail sellers of consumer electronics (VCRs) and 190 consumers. A priori, The inclusion of sellers satisfy the product selection issue; the targeted good had to be available on a variety of brands and countries of origin. Additionally, sellers need to have the opportunity to sell products from several countries (which does not occur, for example, with car salesmen in 
dealerships whose factory is located in the same country). The COD and COA were: Belgium, Brazil, Canada, France, Germany, India, Italy, Japan, Mexico, Morocco, Russia, South Korea and the United States.

Initially, the sellers believed that the COO did not influence the purchasing decisions of household consumers. Nevertheless, the combined data examination data from a random sample of such consumers proved the opposite. The authors named that contradiction as "made in paradox," and suggested as problems for further research, two hypotheses to be explored. The first: the information $\mathrm{COO}$ becomes relevant when, during the evaluation of the product, the consumer becomes aware of its existence. The second: the brand can serve as an approximate view (proxy) to $\mathrm{COO}$, when this information is not available to the consumer. As an opportunity for further research, the authors recommended the study of how the consumer integrates the different dimensions that comprise the information on COO into a simple buying decision. Furthermore, a wider range of brands could be addressed, and details on supplier countries of product components should be exposed to consumers.

Another study involving COO in the B2B context belongs to the late 1990s; Ghymn et al. (1999). The authors searched the most relevant variables for 104 Australian importers. The products not specified. First, there was a qualitative research to accurately raise these variables to these managers in the course of their buying decision process. Subsequently, the authors conducted a quantitative survey covering 480 importers to complete the study. The three most important variables for importers were, from first to third, product quality, long-term dependence on the supplier, and product type (features). The least important variables were trade laws and regulations of the exporting countries, uniqueness of product (in terms of cultural appeal), and packaging. It is worth noting that Australian professionals gave no importance whatsoever to promotional strategies exporters might have used. Notably, the authors did not address such actions.

\subsection{Contributions coming from the 2000s}

Ahmed and d'Astous presented a number of other publications focusing on final consumers of different nationalities (Canadian, Mexican, Thailandese, and Chinese). The authors continued using other variables (often attenuating) of the $\mathrm{COO}$ effect such as brand and warranty - the only case in which the authors involved the B2B environment once again refers to a 2005 publication (Ahmed et al., 2005).

Prior to that, one can notice a prominent article: Ahmed et al. (2002) studied the effect at issue taking into account higher degrees of technological complexity of products - despite focusing on final consumers. The bar has been raised in comparison with the previous communications of these autors, in which the products studied consisted of VCRs, shirts, shoes, refrigerators, cameras and others. Therein, the range of products comprised from computers to cars. According to the main proposal, products of high technological complexity would be better evaluated if coming from countries with a high level of industrialization. Such evaluation would not be favorable if the products had as COO newly industrialized countries - although they had a more positive image when they were countries of assembly only, not design. The authors also aimed to prove that newly industrialized countries exhibit 
remarkable inconsistencies. The highest complexity level their products featured, the worst evaluations they received. Conversely, the simpler their products were, the better evaluations those countries might receive.

As for more technologically complex products, the authors' effort to prove that higher levels of consumer involvement, alongside their technological sophistication level with the product, express a directly related relationship to the $\mathrm{COO}$ evaluation those same consumers are to produce is noteworthy. Research results strongly support the propositions previously mentioned except for the level of technological sophistication, which had partial protection; potentially, newly industrialized countries may present a better picture of the best assemblers for more complex products. In the same way, considering the decision of a given company from a highly industrialized country to assemble their products in newly industrialized countries; it imperative that such enterprise reinforce their communications to the market that their products' design is from their country of origin (Ahmed et al., 2002).

Quester et al. (2000) studied the influence of country-of-origin in high and low risk industrial purchases. They interviewed purchasing agents, Australians and New Zealanders, following the trend of dismembering the $\mathrm{COO}$ into the country of assembly and design, highlighting the quality dimension towards COO. The chosen products were industrial equipment and their spare parts. The analyzed countries were set into three categories: developed, newly industrialized, and developing countries. The first category comprised Japan, France, USA, Sweden, Germany, UK, and Norway. The second category comprised South Korea, Singapore, Taiwan and Honk Kong. The third category comprised Brazil, Mexico, India, Russia, Thailand, and the Philippines.

Indeed, the COO effect directly influences the perception of quality perception on such industrial purchase buying, i.e. industrial goods and components, for both countries, Australia and New Zealand, also occurring at the same intensity for both COA and COD. Hence, interesting results have emerged, such as the fact that Japan taking the first place in the ranking of preference for Australian buyers, both for COD and COA, while that in the ranking for the New Zealanders, the country came to occupy the third position. On the other hand, French suppliers achieved a high score in the ranking of Australians, but listed last in New Zealand, which may reflect a feeling of rejection to France, due to the country's nuclear tests undertaken in the Pacific at the time of the study.

The authors suggest performing such studies in other countries in the B2B context. It is crucial to emphasize the importance which the authors attributed to the dismemberment of the COO into two strands, COD and COA - as performed in other publications - since the studied countries have not earned the same reviews while performing both roles. In addition, B2B marketing professionals should be cautious about the use of information on COO, who should only bring such fact to light after an adequate insight into the possible impact that this information can produce among international buyers.

Through a different approach from all prior publications; La et al. (2005) evaluated the COO effect on consultants, engineers, project managers, and other business services. The authors sought to discover the explanation for the value the customer perceives in the B2B 
environment when the service provider is from a foreign country. Moreover, if this evaluation, through different contingency conditions, could change (e.g., higher or lower perception of the country-of-origin versus high or low customer buying experience). Survey respondents were professionals in Malaysia and Thailand. The countries of the service providers were U.S., Britain, Australia, the Netherlands, Germany, and Singapore. A small proportion refers to other countries, nearly $6 \%$ of the total.

As Quester et al. (2000); La et al. (2005) started the process of data collection with in-depth interviews, primarily to raise variables that implied the greater impact on the evaluation of the purchaser of "imported" service in the B2B context. The variables found were: technical and interpersonal skills, consumer orientation, innovation, reputation, value given by the customer and their satisfaction. Subsequently, the authors initiated a search for a larger scale, with quantitative questionnaires.

Among the discoveries of La et al. (2005), it is important to note that when organizational clients have a positive image upon persons of a given country, they transfer that same positivity to the image of the company providing the service. If the image the person from the country is negative, the clients' evaluation tends to turn to the technical expertise of the worker providing the service and the innovation level of the service providing company. Likewise, when a client has a strong impression towards the abilities and skills found in a given country, the company's performance evaluation stands for how much or until which degree that business is client-oriented. If this assessment is negative, the performance of the company providing the service will be evaluated on the level of innovation and reputation, rather than the skills displayed by the person providing the service. The company's reputation has a greater weight on the performance evaluation of the service it provides; if the customer has a positive image of the country as a "provider" of services. However, if this image is negative, the evaluation rests with the interpersonal skills of the person providing the service. If the client has a negative image about the people of a given country, even a satisfactory performance will not bring high impact on the customer's evaluation, which may be the result of strong beliefs and a structure formed in the consumer's mind upon that country. On the other hand, if the image that the customer has on persons of that country is positive, and the service provider offers good technical quality, the assessment will be certainly more positive.

As a window for future research, La et al. (2005) suggested the conduction of similar studies in "cross-cultural" environments such as the Western and Eastern Hemispheres. The authors also suggest researching the circumstances and decision-making elements that lead organizational buyers prefer to pay by foreign rather than local professional services. Finally, the authors indicate that there is still research to be done with in-depth interviews, not only with buyers, but also with those who sell to other countries.

In a subsequent multidisciplinary study, having COO broken into COD and COA; Ahmed et al. (2005) compared the effects that brand, quality assurance, and price (as additional attributes) have on country-of-design and country-of-assembly (in B2B and B2C environments). The findings show that organizational buyers have the country of design as an important extrinsic attribute, especially regarding the quality assessment for high-tech 
products. Under those circumstances, such attribute is more important than the country of assembly. Thus, since the study was restricted to Canada, more realistic results demand the consideration of a broader number of countries, brands and products in the analysis.

Five years later, Eggertsson (2010) investigated the organizational purchase decision for air conditioning and refrigeration devices. The purchase decision maker had several choices of brands and countries of origin. The brand served as a decisive factor in the analysis because the U.S. not only developed the technology, but also hold most of the brands of refrigeration equipment available in the market.

Eggertsson (2010) gave a more solid approach to the brand in comparison to the other authors who also had studied the effects of $\mathrm{COO}$ in $\mathrm{B} 2 \mathrm{~B}$ transactions. The study encompassed a total of 14 brands. The author sought to investigate the degree of influence that price, technical information, post-sale support, spare parts availability, supplier's reputation, and delivery reliability had on the country of manufacture and Country-of-Brand-Origin (COBO). The countries of origin considered were: U.S., EU countries, and Japan. Respondents from nineteen countries contributed to this analysis.

Regarding COBO and COM, Eggertsson (2010) found that respondents would prefer to pay more for compressors manufactured in Europe, Japan or the USA. Additionally there were no significant difference in ranking among them, and the amounts would figure up to nearly five thousand U.S. dollars more, against the products manufactured in the BRIC countries (Brazil, Russia, India and China). Within the "price" dimension, the COM ended up being more important than the brand's country-of-origin per se. Considering the results from crossing dimensions between $\mathrm{COBO}$ and $\mathrm{COA}$; the resulting ranking of importance, from first to fourth places respectively refers to the price, confidence in supplier and parts availability, post-sale support, and supplier reputation. Nevertheless, the scores attributed to the five dimensions were very similar.

Eggertsson (2010) concludes his study by stating that, in future studies, cultural variables of the country of purchase must be crossed with the suppliers' COO effect, coupled with Cattin et al. (1982) who had also raised this need. The author also suggests the crossing of variables with $\mathrm{COBO}$ and COA in other markets as variously as possible, especially across industries.

Finally, Chen and Su (2011) presented a publication showing that, despite the increasing focus on brands within the B2B environment, scarce research has been done to clearly understand the role that such brands play internationally. By the same token, the author sought to investigate the effects that the COM and COD had in order to explain the variation perceived in the brand value assessment from global organizational buyers - especially those from newly industrialized countries as Taiwan, in compliance with the research topic.

The novelty of this work consists of the authors placing the concept of "brand value" within the organizational context. The main goal of the study was to test the influences that both COD and COM had on brand value to then investigate the process that B2B buyers undertake to assess the value of a brand when faced with a single or multiple cues. The authors sought to examine the value of the brand as a dependent variable within B2B markets. In this sense, 
they explain how the perceived quality, brand awareness, COM and COD can be the sources of the value of industrial brand. Among the ten hypotheses of the research, the ones that were related to the country-of-origin were those in which COM, COD, and perceived service quality had a positive association with brand value. The other hypotheses attempted to relate perceived value and performance in the distribution of industrial products with the quality of those with information about the company's services. In addition, other hypotheses have sought to relate the service providers with the services per se; brand recognition with the value of industrial brand; and brand value with loyalty to the brand.

Chen and Su (2011) found that both COD and COA of products exert great influence on organizational buyers from other countries, provided that the conditions of purchase are not yet fully developed; i.e., in this scenario, COD and COM stand as single cues. However, these elements lose strength when considered altogether with other cues. According to the authors, such finding had already been brought to the light in the past: studies associating $\mathrm{COO}$ with single and multiple cues have been inconclusive so far. Such inconsistency represents a managerial challenge in view of COD and COM. B2B marketing managers are in charge of brand development and communication. While working in the field of international markets, these professionals must inculcate a clear awareness in the minds of consumers in regard to the brands they represent in order to provide a proper image through the consolidation of the reputation of enterprises in both dimensions: internal (product) and external (country-of-origin).

Concerning the crossing between B2B and COO, the 2000s exhibits a broad range of studies due to the abundant number of countries-of-origin that analyzed. The systematic variation of buying complexity, which had been left as a gap in the middle 1970s (Håkansson and Wootz, 1975), and subsequently covered by Ahmed and d'Astous (1993), had once again gained attention, having both products and their spare parts, and services evaluated. Henceforth, it is noted that the brand gained more strength (Eggertsson, 2010) and, in the 2010s, Chen and Su (2011) innovated by drawing a parallel between COO and brand equity. The authors have highlighted the importance of communication between companies from different countries in the B2B context. In the second case, the overall result shows that, regardless the higher expenditure, buyers preferred to buy compressors from countries such as Japan, the U.S. or a European country instead of buying the same products from Brazil. This preference remained unaltered even if the brand belonged to another country.

Figure 1 shows a chronological synthesis of the 16 publications in the marketing literature displayed in this paper. 


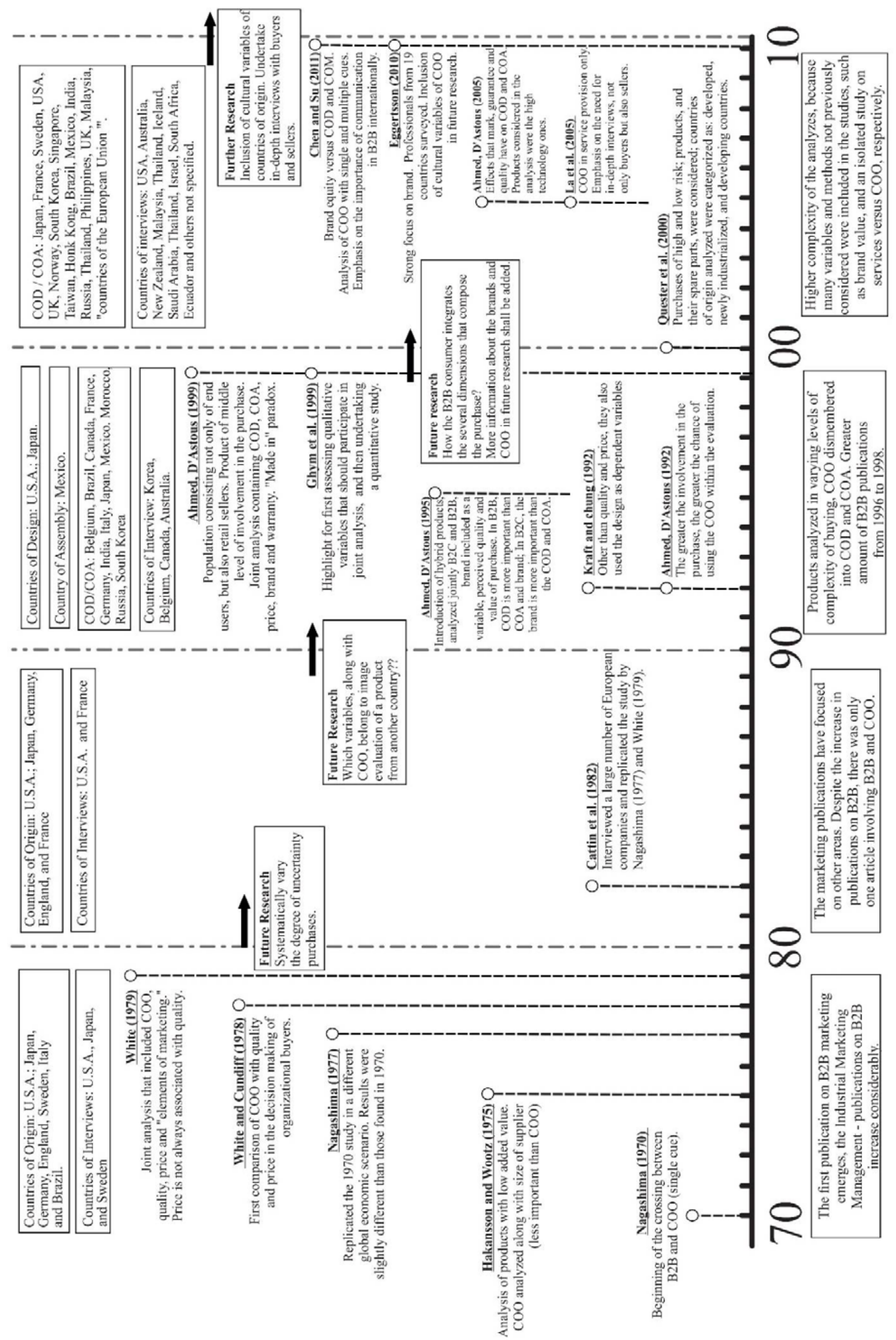

Figure 1. Evolution of the studies involving B2B and COO over the last 40 year 


\section{Conclusion}

The 1970s notably showed a considerable increase in the number of journals and publications that address the B2B marketing. At that moment, the first publications covering simultaneously the context of organizational purchases and the country-of-origin on perceptions of organizational consumers in evaluating the effect of foreign products. In the following years, however, these two subjects met again a few times in the literature, either due to the relatively limited amount of available papers in the global B2B marketing literature, or by virtue of the difficulties in obtaining information from the professionals involved in the corporate purchasing process.

The 1970's served as an introduction to the approach of the theme country-of-origin effect within the B2B environment. In the first half of the decade, the existence of a relationship between these constructs was proved. Subsequently, by the second half of the decade, dimensions such as price and quality have gained greater notoriety. Respondents - all organizational buyers - were Japanese, Swedish and American. The analyzed countries were USA, Japan and some others from Europe. Additionally, that historical period served as scenario for a global change in the economic situation that directly impacted the opinion of respondents. Further research opportunities include the need to vary the uncertainty degree of organizational purchases, which is closely related to the products' technical complexity; being subsequently revisited in over a decade later.

In the 1980s, studies involving the image of countries and B2B marketing had no greater representation, despite the emergence of later publications such as the Journal of Business and Industrial Marketing and the Advances in Business Marketing and Purchasing. Therefore, it was proposed the possibility of in-depth investigation to identify attributes that, along with COO, comprise the evaluation of organizational buyers when selecting products from other countries. This theoretical gap gained significant appraisal over the next two decades, when the $\mathrm{COO}$ concept was divided into COD, COA and COM together with the immersion of dimensions such as brand or product quality in the surveys.

During the 1990s, the effect that the country of origin for products of low or high complexity exerts on household and organizational consumers became more expressive, as proposed at the end of the 1970s. Recurrently other variables other than the COO were used. The objective was to determine whether this construct could be alleviated by these variables, or whether they would serve as a proxy to the construct. The countries of origin of the products analyzed comprised a spectrum of levels ranging from newly industrialized to developed countries. Alternately, those countries assumed the roles of COD and COA.This analysis comes from studies on the country of origin effect in the $\mathrm{B} 2 \mathrm{C}$ environment, serving as a novelty to the B2B context. Still, it is suggested that the forthcoming research address the process of integration of the various dimensions that make up the decision-making processes that organizational buyers adopt during the evaluation and choice of products from countries other than theirs.

Finally, the 2000s brought the most complex analysis of all decades studied. That is due to the engagement of an expressive and comprehensive number of countries; as well as for mixing quantitative research and exploratory research, in addition to addressing constructs 
such as brand equity as a proxy for COM and COD, besides price, guarantee and quality on $\mathrm{COD}$ and COA. For the first time, the COO was analyzed separately with services in the B2B environment, and it has also been studied for purchases with the highest level of complexity explored so far (high technology products). For further research, we suggest addressing cultural variables of the countries of origin. Additionally, we recommend including a return movement to qualitative analysis to obtain more dimensions that, together with the made in information, may influence the attitude and the purchase decision of organizational consumers.

Despite the low number of publications on the topic over the past 30 years, the literature that jointly addressed the issues country-of-origin effect and organizational marketing shows that the very conditions of market evolution required greater refinement of research. This phenomenon took place due to aspects such as the level of technological complexity of products, a more active participation of various countries in international commercial transactions, and the internationalization process of many companies' operations. Again, it is important to emphasize the importance of information and the decision of companies to install units in other countries, usually in developing or newly industrialized countries, for the execution of design, manufacturing and assembly of their products.

In essence, most of the theoretical gaps that emerged over that period has been covered. However, the end of the 2000 s, once again opened a possibility of further deepening in the subject, with regard to the in-depth evaluation of attributes that have not been addressed such as the culture of the countries of origin regarding the evaluation and purchase decision of organizational buyers or even studies encompassing an increased level of complexity of products traded between countries.

This paper brought to light the work published in the literature involving the topics business-to-business marketing and the country-of-origin effect, as well as the direction that both have followed together over the decades. It was seen that the research on the subject is of a diminutive universe, and proposals for future research were suggested by authors in the field, so that current researchers are now able to identify which gaps are yet to be studied. As a conclusion of this literature review, the graphical representation displayed the authors and their research, the countries involved in the assessments and, the theoretical gaps for further studies.

Considering that this study was mostly theoretical, and as such, grounded its analysis on existing literature, the results are limited due to its exploratory nature.

\section{Acknowledgement}

This research has received financial support from $\mathrm{CNPq}$ (Brazil).

\section{References}

Ahmed, S. A., \& D'Astous, A. (1993). Cross-national evaluation of made-in concept using multiple cues. European Journal of Marketing, 27(7), 39-52. http://dx.doi.org/10.1108/03090569310040343

Ahmed, S. A., \& D'Astous, A. (1995). Comparison of country-of-origin effects on household and organizational buyers' product perceptions. European journal of Marketing, 29(3), 35-51. http://dx.doi.org/10.1108/03090569510145741 
Ahmed, S. A., \& D'Astous, A. (1996). Country-of-origin and brand effects: a multi-dimensional and multi-attribute study. Journal of International Consumer Marketing, 9(2), 93-115. http://dx.doi.org/10.1300/J046v09n02_05

Ahmed, S. A., D’Astous, A., \& Champagne, C. (2005). Country images of technological products in Taiwan. Asia Pacific Journal of Marketing and Logistics, 17, 44-70. http://dx.doi.org/10.1108/13555850510672331

Ahmed, S. A., d'Astous, A., \& Eljabri, J. (2002). The impact of technological complexity on consumers' perceptions of products made in highly and newly industrialised countries. International Marketing Review, 387-407. http://dx.doi.org/10.1108/02651330210435681

Baumgartner, G., \& Jolibert, A. (1977). The perception of foreign products in France. Advances in consumer research, 5, 603-605. Retrieved from: http://acrwebsite.org/volumes/9490/volumes/v05/NA-05

Cattin, P., Jolibert, A., \& Lohnes, C. (1982). A cross-cultural study of 'made in' concepts. Journal of International Business Studies, 13(3), 131-141. Retrieved from: http://www.jstor.org/stable/154470

Chen, Y.M., \& Su, Y.F. (2011). Do country-of-manufacture and country-of-design matter to industrial brand equity? Journal of business \& Industrial Marketing, 1(27), 57-68. http://dx.doi.org/10.1108/08858621211188966

Eggertsson, M. (2010). Country-of-Origin and Branding in a B2B Context, Dissertation, Nova Southeastern University, available at: http://search.proquest.com/docview/756900130 (accessed 30 November 2013).

Ghymn, K., Liesch, P., \& Mattsson, J. (1999). Australian import managers' purchasing decision behavior: an empirical study. International Marketing Review, 16(3), 202-216. http://dx.doi.org/10.1108/02651339910274693

Giraldi, J. M. E., Ikeda, A. A., \& Campomar, M. C. (2011). Reasons for country image evaluation: A study on China image from a Brazilian perspective. Journal of Database Marketing \& Customer Strategy Management, 18, 97-107. http://dx.doi.org/10.1057/dbm.2011.10

Håkansson, H., \& Wootz, B. (1975). Supplier Selection in an International Environment-An Experimental Study. Journal of Marketing Research, 12(1), 46-51. http://dx.doi.org/10.2307/3150657

Knight, J.G., Holdsworth, D. K., \& Mather, D. W. (2007). Country-of-origin and choice of food imports: an in-depth study of European distribution channel gatekeepers. Journal of International Business Studies, 38, 107-125. Retrieved from: http://www.jstor.org/stable/4540405

Kraft, F. B., \& Chung, K. H. (1992). Korean importer perceptions of US and Japanese industrial goods exporters. International Marketing Review, 9(2), 59-73. http://dx.doi.org/10.1108/02651339210012456

La, V. Q., Patterson, P.G., \& Styles, C.W. (2005). ISBM Report 17-2005: Client perceived value in professional $B 2 B$ services: an international perspective in developing economies, Institute for the Study of Business Markets, The Pennsylvania State University.

LaPlaca, P. J. (2008). Commentary on 'The Essence of Business Marketing...' by Lichtenthal, 
Mummalaneni, and Wilson: the JBBM comes of age. Journal of Business-to-Business Marketing, 15(2), 180-191. http://dx.doi.org/10.1080/15470620802020143

LaPlaca, P.J., \& Katrichis, J.M. (2009). Relative presence of business-to-business research in the marketing literature, Journal of Business-to-Business Marketing, 16(1-2), 1-22. http://dx.doi.org/10.1080/10517120802484213

Laroche, M. F.R.S.C., Papadopoulos, N., Heslop, L., \& Bergeron, J. (2003). Effects of subcultural differences on country and product evaluations. Journal of Consumer Behaviour, 2(3), 232-247. http://dx.doi.org/10.1002/cb.104

Nagashima. A. (1970). A comparison of Japanese and U.A. attitudes toward foreign products. Journal of Marketing, 34(1), 68-74. http://dx.doi.org/10.2307/1250298

Nagashima. A. (1977). A Comparative Made in product image: survey among japanese businessmen. Journal of Marketing, 41(3), 95-100. http://dx.doi.org/10.2307/1250943

Peterson, R. A., \& Jolibert, A. J. (1995). A meta-analysis of country-of-origin effects. Journal $\begin{array}{lllr}\text { of International } \quad \text { Business } & \text { 883-900. }\end{array}$

http://dx.doi.org/10.1057/palgrave.jibs. 8490824

Quester, P.G., Dzever, S., \& Chetty, S. (2000). Country-of-origin effects on purchasing agents' product perceptions: an international perspective. Journal of Business \& Industrial Marketing, 15(7), 479-489. http://dx.doi.org/10.1108/08858620010351706

Reid, D. A., \& Plank, R. E. (2000). Business Marketing Comes of Age: A Comprehensive Review of the Literature. Journal of Business-to-Business Marketing, 7, 9-181. http://dx.doi.org/10.1300/J033v07n02_02

Schooler, R. (1965). Bias phenomena attendant to the marketing of foreign goods in the US. Journal of International Business Studies, 2(1), 71-80. http://dx.doi.org/10.1057/palgrave.jibs.8490732

Urbonavičius, S., \& Gineikienè, J. (2009). Importance of the product country-of-origin factor on purchasing process in the context of globalization. Ekonomika, 85, 37-44.

Usunier, J.C. (2006). Relevance in business research: the case of country-of-origin research in marketing. European Management Review, 3(1), 60-73. http://dx.doi.org/10.1057/palgrave.emr.1500049

White, P. D. (1979). Attitudes of us purchasing managers toward industrial products manufactured in selected western european nations. Journal of International Business Studies, 10(1), 81-90. Retrieved from: http://www.jstor.org/stable/154372

Wilkie, W. L., \& Moore, E. S. (2003). Scholarly research in marketing: exploring the" 4 Eras" of thought development. Journal of Public Policy \& Marketing, 22(2), 116-146. http://dx.doi.org/10.1509/jppm.22.2.116.17639

\section{Copyright Disclaimer}

Copyright for this article is retained by the author(s), with first publication rights granted to the journal.

This is an open-access article distributed under the terms and conditions of the Creative Commons Attribution license (http://creativecommons.org/licenses/by/3.0/). 